NASA/TM-2007-214826

\title{
Performance and Comparison of Lithium-Ion Batteries Under Low-Earth-Orbit Mission Profiles
}

Concha M. Reid

Glenn Research Center, Cleveland, Ohio

Marshall C. Smart and Ratnakumar V. Bugga

Jet Propulsion Laboratory, Pasadena, California

Michelle A. Manzo and Thomas B. Miller

Glenn Research Center, Cleveland, Ohio

Rob Gitzendanner

Yardney Technical Products/Lithion, Inc., Pawcatuck, Connecticut 


\section{NASA STI Program . . . in Profile}

Since its founding, NASA has been dedicated to the advancement of aeronautics and space science. The NASA Scientific and Technical Information (STI) program plays a key part in helping NASA maintain this important role.

The NASA STI Program operates under the auspices of the Agency Chief Information Officer. It collects, organizes, provides for archiving, and disseminates NASA's STI. The NASA STI program provides access to the NASA Aeronautics and Space Database and its public interface, the NASA Technical Reports Server, thus providing one of the largest collections of aeronautical and space science STI in the world. Results are published in both non-NASA channels and by NASA in the NASA STI Report Series, which includes the following report types:

- TECHNICAL PUBLICATION. Reports of completed research or a major significant phase of research that present the results of NASA programs and include extensive data or theoretical analysis. Includes compilations of significant scientific and technical data and information deemed to be of continuing reference value. NASA counterpart of peer-reviewed formal professional papers but has less stringent limitations on manuscript length and extent of graphic presentations.

- TECHNICAL MEMORANDUM. Scientific and technical findings that are preliminary or of specialized interest, e.g., quick release reports, working papers, and bibliographies that contain minimal annotation. Does not contain extensive analysis.

- CONTRACTOR REPORT. Scientific and technical findings by NASA-sponsored contractors and grantees.
- CONFERENCE PUBLICATION. Collected papers from scientific and technical conferences, symposia, seminars, or other meetings sponsored or cosponsored by NASA.

- SPECIAL PUBLICATION. Scientific, technical, or historical information from NASA programs, projects, and missions, often concerned with subjects having substantial public interest.

- TECHNICAL TRANSLATION. Englishlanguage translations of foreign scientific and technical material pertinent to NASA's mission.

Specialized services also include creating custom thesauri, building customized databases, organizing and publishing research results.

For more information about the NASA STI program, see the following:

- Access the NASA STI program home page at http://www.sti.nasa.gov

- E-mail your question via the Internet to help@sti.nasa.gov

- Fax your question to the NASA STI Help Desk at 301-621-0134

- Telephone the NASA STI Help Desk at 301-621-0390

- Write to: NASA Center for AeroSpace Information (CASI) 7115 Standard Drive Hanover, MD 21076-1320 
NASA/TM-2007-214826

AIAA-2006-4042

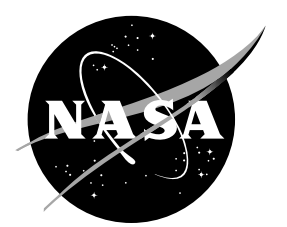

\section{Performance and Comparison of Lithium-Ion Batteries Under Low-Earth-Orbit Mission Profiles}

Concha M. Reid

Glenn Research Center, Cleveland, Ohio

Marshall C. Smart and Ratnakumar V. Bugga

Jet Propulsion Laboratory, Pasadena, California

Michelle A. Manzo and Thomas B. Miller

Glenn Research Center, Cleveland, Ohio

Rob Gitzendanner

Yardney Technical Products/Lithion, Inc., Pawcatuck, Connecticut

Prepared for the

Fourth International Energy Conversion Engineering Conference and Exhibit (IECEC)

sponsored by the American Institute of Aeronautics and Astronautics

San Diego, California, June 26-29, 2006

National Aeronautics and

Space Administration

Glenn Research Center

Cleveland, Ohio 44135 


\section{Acknowledgments}

This work was performed in-house at the NASA Glenn Research Center (GRC) and Jet Propulsion Laboratory (JPL). Funding for this work is provided by the Space-Rated Lithium-Ion Battery Task under the Exploration Systems Mission Directorate of NASA. The authors would like to acknowledge Chelsea Yazzie, NASA summer intern and student at Diné College for her assistance with this paper.

This report contains preliminary findings, subject to revision as analysis proceeds.

Trade names and trademarks are used in this report for identification only. Their usage does not constitute an official endorsement, either expressed or implied, by the National Aeronautics and Space Administration.

Level of Review: This material has been technically reviewed by technical management.

Available from

NASA Center for Aerospace Information 7115 Standard Drive

Hanover, MD 21076-1320
National Technical Information Service 5285 Port Royal Road Springfield, VA 22161 


\title{
Performance and Comparison of Lithium-Ion Batteries Under Low-Earth-Orbit Mission Profiles
}

\author{
Concha M. Reid \\ National Aeronautics and Space Administration \\ Glenn Research Center \\ Cleveland, Ohio 44135 \\ Marshall C. Smart and Ratnakumar V. Bugga \\ Jet Propulsion Laboratory \\ Pasadena, California 91109 \\ Michelle A. Manzo and Thomas B. Miller \\ National Aeronautics and Space Administration \\ Glenn Research Center \\ Cleveland, Ohio 44135 \\ Rob Gitzendanner \\ Yardney Technical Products/Lithion, Inc. \\ Pawcatuck, Connecticut 06379
}

\begin{abstract}
The performance of two $28 \mathrm{~V}, 25$ Ah lithium-ion batteries is being evaluated under low-Earth-orbit mission profiles for satellite and orbiter applications. These space flight-qualified batteries were designed and fabricated by Lithion, Inc. (Yardney Technical Products) for the 2001 Mars Surveyor Program Lander, the first major NASA mission that baselined lithium-ion battery technology. Lithium-ion battery chemistry was an enabling technology for the mission because of its ability to provide low temperature operation in a lightweight and compact battery design. The Mars Surveyor Program mission was cancelled before launch, however, the Lander batteries had already been built and flight-qualified. Lithium-ion batteries are being baselined for increasingly more missions, including missions in lowEarth-orbit and geosynchronous orbit. These mission conditions are more challenging for lithium-ion batteries than a short mission on Mars. Many more cycles are required for operation in low-Earth-orbit and a much longer calendar life is required for operation in either low-Earth-orbit or geosynchronous orbit. A ground test program was established that utilized the Lander batteries from the original mission to demonstrate performance and life under various mission conditions. This paper presents results of the low-Earth-orbit (LEO) portion of the testing that is being conducted at NASA Glenn Research Center (GRC) and NASA Jet Propulsion Laboratory (JPL). The batteries discussed are currently undergoing life testing and have each achieved over 12,000 cycles to 40 percent depth-of-discharge. Each battery is cycling at a different temperature, one at $23{ }^{\circ} \mathrm{C}$ and the other at $0{ }^{\circ} \mathrm{C}$. In addition to cycling under lowEarth-orbit conditions, the batteries have been characterized at 500 to 1000 cycle intervals throughout the life testing to observe their capacity and DC impedance changes. Because the batteries are not equipped with cell balancing electronics, cell balancing is manually performed on each battery when cell voltage dispersion exceeds the established threshold. The performance of the batteries will be discussed individually and their performance relative to each other at the different test conditions will be compared.
\end{abstract}




\section{Introduction}

Lithium-Ion (Li-ion) batteries are being evaluated by the National Aeronautics and Space Administration (NASA) and other partner organizations in order to assess their capability to perform under a variety of conditions and temperatures in low-Earth-orbit (LEO) and other space and planetary mission regimes. This paper reports the results of ongoing LEO life-testing on two $28 \mathrm{~V}, 25 \mathrm{Ah} \mathrm{Li}$-ion batteries and compares their performance. The batteries were originally designed and built for the 2001 Mars Surveyor Program Lander. They are being tested at NASA Glenn Research Center (GRC) and NASA Jet Propulsion Laboratory (JPL). Figure 1 shows a representative battery assembly in its original configuration. Two battery stacks and connectors are shown. The unusual orientation of the stacks in this battery assembly was driven by the volume constraints of the Lander.

Each battery contains eight prismatic Li-ion cells connected in series. The cells contain a mesocarbon microbeads (MCMB) anode, a lithium nickel cobalt oxide $\left(\mathrm{LiNiCoO}_{2}\right)$ cathode, and a liquid organic electrolyte. To meet the requirements of the original mission, a special electrolyte formulation was incorporated into the cells to improve the low temperature performance of the batteries. When Li-ion cells are operated at low temperatures, low temperature electrolytes can enhance the conductivity in the cells, can improve the redox stability at the electrodes, and can improve rate capability over cells that use standard electrolytes (ref. 1).

Manufacturer characteristics of the batteries are shown in table 1. The batteries do not contain any charge balancing electronics. It was determined during the design process of the battery for the original mission that charge control electronics were unnecessary to keep the cells balanced for the expected duration of the mission (90 cycles).

The two batteries were built using cells from the same manufacturing lot. Cells were selected for each battery based on several criteria that included capacity and energy efficiency at different temperatures, capacity and energy efficiency at different discharge rates, and voltage drop on stand after charging (a measurement of the rate of self discharge at open circuit). The criteria were evaluated on a weighted scale. Weightings were determined based on the requirements of the original mission. Voltage drop on stand after charging had the highest weighting of 50 percent.

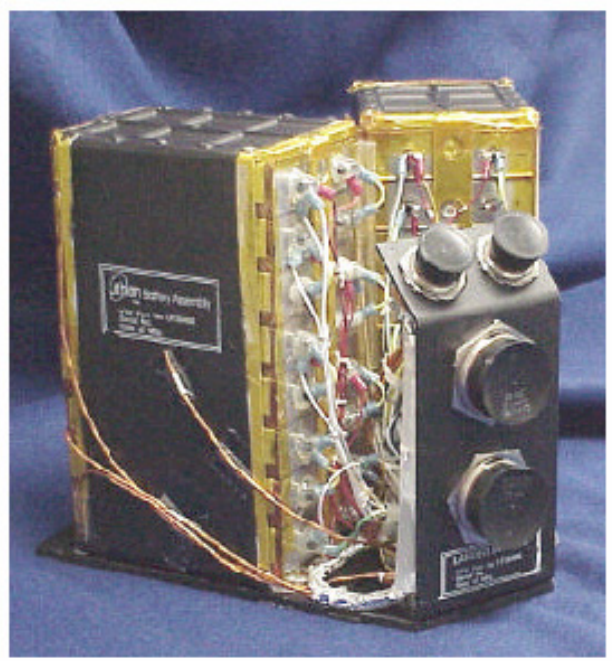

Figure 1.-2001 Mars Surveyor Program Lander batteries (Source: Yardney Technical Products). 


\section{Background}

Currently, nickel hydrogen $\left(\mathrm{Ni}-\mathrm{H}_{2}\right)$ and nickel-cadmium $(\mathrm{Ni}-\mathrm{Cd})$ batteries provide energy storage for the majority of satellites in LEO. Li-based battery technology initially broke ground in its utilization in the US space program due to its ability to enable missions operating in low temperature environments, such as Mars. In addition to its low temperature capability, Li-ion technology offers great improvements in mass, volume, efficiency, shelf life, and operating temperature range over nickel-based and other secondary (rechargeable) alkaline battery chemistries. Such improved capabilities are desirable for LEO missions and beyond as NASA seeks technologies to enable the Vision for Space Exploration human missions to the moon and Mars.

The 2001 Mars Surveyor Program was the first major NASA mission that baselined Li-ion battery technology. Five spaceflight batteries of the same design were built for the program. Following the cancellation of the mission due to programmatic issues, a coordinated plan was developed among several organizations to evaluate the performance of all five batteries under a variety of conditions. In addition to GRC and JPL, other participating organizations include the Naval Research Laboratory (NRL) and the Air Force Research Laboratory (AFRL). The batteries have undergone testing in various LEO, geosynchronous orbit (GEO), and planetary mission profile regimes.

GRC's role in the test program is to perform low temperature LEO testing at specific orbital parameters. NASA JPL's role includes the evaluation of two batteries. The first battery is being evaluated under LEO orbit conditions at room temperature. The second battery was evaluated under a Mars mission profile. Reports on the individual battery performance and other testing efforts with cells of the same design from which these batteries were built are available in the literature (refs. 2 to 6). As a result of these and other related test programs, this battery design has been baselined for the 2007 Phoenix Mars Lander scout mission.

An essential performance metric for batteries operating in LEO is long cycle life. Since satellites in LEO typically operate for five years or more while delivering electrical energy during approximately 16 cycles per day, the energy storage system must be capable of providing upwards of 30,000 cycles. Li-ion batteries have recently been launched on a few select missions to LEO that only require low cycle lives.

TABLE 1.-MANUFACTURER SPECIFICATIONS OF THE MARS SURVEYOR PROGRAM LANDER BATTERY

\begin{tabular}{|c|c|}
\hline $\begin{array}{l}\text { Cell/battery } \\
\text { manufacturer }\end{array}$ & Yardney Technical Products, Inc. \\
\hline Nameplate capacity & $25 \mathrm{Ah}$ \\
\hline Rated capacity & $30 \mathrm{Ah}$ at $\mathrm{C} / 5$ at $20^{\circ} \mathrm{C} ; 24 \mathrm{Ah}$ at $\mathrm{C} / 5$ at $-20{ }^{\circ} \mathrm{C}$ \\
\hline Nominal voltage & $28.8 \mathrm{~V}$ \\
\hline Operating temperature & -20 to $40^{\circ} \mathrm{C}$ \\
\hline Cell type & Prismatic \\
\hline Number of cells & 8 \\
\hline Anode & Mesocarbon microbeads (MCMB) \\
\hline Cathode & $\mathrm{LiNiCoO}_{2}$ \\
\hline Electrolyte & 1.0 $\mathrm{M} \mathrm{LiPF}_{6} \mathrm{EC}+\mathrm{DMC}+\mathrm{DEC}(1: 1: 1)$ \\
\hline Design mission & $\begin{array}{l}\text { Storage: Up to } 2 \text { years, } 1 \text { year of which during cruise to } \\
\text { Mars at } 0 \text { to } 30{ }^{\circ} \mathrm{C} \\
\text { Entry, descent and landing (EDL) on Mars: Several } 2 \mathrm{C} \\
\text { pulses, } 100 \text { milliseconds in duration at } 0{ }^{\circ} \mathrm{C} \\
\text { Operation on Mars: Minimum of } 90 \text { cycles, typical } \\
\text { discharge of } \mathrm{C} / 5 \text { at a maximum of } 50 \text { percent DOD at } \\
-20 \text { to } 40^{\circ} \mathrm{C}\end{array}$ \\
\hline $\begin{array}{l}\text { Special operating } \\
\text { considerations }\end{array}$ & Can operate under any orientation and in zero-gravity \\
\hline
\end{tabular}

Source: Yardney Technical Products, JPL (ref. 4) 
Real-time life testing of Li-ion batteries continues to be essential to assess multi-cell battery-level performance, establish cycle life, and otherwise validate the chemistry for its spaceflight readiness for LEO and other types of aerospace missions. Results reported on in this paper contribute valuable data to the aerospace battery community for the ongoing assessment of the life performance of aerospace Li-ion battery technologies. The findings will help to validate the technology for its widespread use in manned and unmanned missions.

\section{Experimental}

The test regimes for the batteries consist of pre-LEO characterization, LEO cycling, periodic characterization, and cell balancing. The test conditions of the batteries are summarized in table 2 .

Testing on the batteries is performed using commercial battery cyclers. Current, battery voltage, cell voltages, and cell temperatures (outside case) are continually monitored. The batteries are housed within environmental chambers that are held at the test temperatures during LEO testing and periodic characterization. Cell balancing is conducted at room temperature because portions of this procedure must be done manually. After cell balancing, the batteries are stabilized at the test temperatures for at least $24 \mathrm{hr}$ before characterization and testing continues.

\section{Pre-LEO Characterization}

To compare the life performance of the batteries that were cycling under different conditions, it was important to collect a set of baseline measurements at identical operating conditions for both batteries. Pre-LEO characterization included wake-up procedures (if necessary), cell balancing, baseline capacity tests, and baseline impedance tests.

Pre-LEO Characterization was begun by performing an initial set of capacity measurements on each battery. Both batteries delivered greater than nameplate capacity during these measurements, so wake-up procedures were not necessary. Cell balancing was performed on each battery after this initial set of measurements had been made to bring the cell voltages closer together and improve the battery operation.

Several baseline capacity measurements were performed on the batteries to determine their full capacities under different conditions. Each test organization developed an individual test matrix to observe the capacity delivered by their battery at specific conditions of interest. There was some overlap built into the baseline capacity measurement test matrices such that at least two tests at identical conditions were performed on both batteries. These two identical tests are described further below.

In the first of the identical tests, the batteries were soaked at $20^{\circ} \mathrm{C}$ for at least $24 \mathrm{hr}$. They were then charged using a constant current, constant voltage (CCCV) regime. The batteries were charged at $\mathrm{C} / 5$ to $32 \mathrm{~V}$ on the battery level or until any cell reached $4.05 \mathrm{~V}$. The voltage was then held constant while the current was allowed to taper until it reached $\mathrm{C} / 50$. The batteries were then discharged at $\mathrm{C} / 5$ to $24 \mathrm{~V}$ on the battery level or until any cell reached $2.5 \mathrm{~V}$. At these conditions, the battery being tested at GRC, which we have designated here as Battery G, had a slightly higher capacity than the battery being tested at JPL, which we have designated here as Battery J. Battery G delivered 30.6 Ah and Battery J delivered $30.1 \mathrm{Ah}$. 
TABLE 2.-BATTERY TEST CONDITIONS AND PROCEDURES

\begin{tabular}{|c|c|c|}
\hline \multicolumn{2}{|c|}{ Test Conditions } & Test Procedures \\
\hline \multicolumn{2}{|l|}{ Pre-LEO } & $\begin{array}{l}\text { Perform baseline full capacity measurements for one set of conditions. } \\
\text { Balance cells (as given below in this table). } \\
\text { Perform baseline full capacity measurements ( } 100 \text { percent DOD) for several conditions and } \\
\text { temperatures. If test temperature will change, soak battery for at least } 24 \mathrm{hr} \text { at new test } \\
\text { temperature before test. } \\
\text { Perform baseline current-interrupt impedance tests at } 20 \text { and } 0{ }^{\circ} \mathrm{C} \text { (as given below in this } \\
\text { table). }\end{array}$ \\
\hline \multicolumn{2}{|l|}{ LEO } & $\begin{array}{l}\text { Battery G: At } 0{ }^{\circ} \mathrm{C} \text {, charge at a constant current of } \mathrm{C} / 2(12.5 \mathrm{~A}) \text { to } 32 \mathrm{~V} \text { or until any cell } \\
\text { reaches } 4.05 \mathrm{~V} \text {. Hold voltage constant and continue to charge for the remainder of the } \\
55 \mathrm{~min} \text { charge period. Discharge at approximately } 0.7 \mathrm{C}(17.14 \mathrm{~A}) \text { for } 35 \text { min (to } 40 \text { percent } \\
\text { DOD). } \\
\text { Battery J: At } 23{ }^{\circ} \mathrm{C} \text {, charge at a constant current of } \mathrm{C} / 2(12.5 \mathrm{~A}) \text { to } 30.4 \mathrm{~V} \text { or until any cell } \\
\text { reaches } 4.05 \mathrm{~V} \text {. Hold voltage constant and continue to charge for the remainder of the } \\
55 \text { min charge period. Discharge at approximately } 0.7 \mathrm{C}(17.5 \mathrm{~A}) \text { for } 35 \text { min (to } 40 \text { percent } \\
\text { DOD). } \\
\text { Failure is defined when EODV is } 24 \text { or } 2.5 \mathrm{~V} \text { on any cell. }\end{array}$ \\
\hline \multirow{2}{*}{$\begin{array}{l}500 \text { and } \\
1000 \text { cycle } \\
\text { characterization }\end{array}$} & $\begin{array}{l}100 \text { percent } \\
\text { DOD } \\
\text { capacity } \\
\text { test }\end{array}$ & $\begin{array}{l}\text { Continue LEO discharge to } 24.0 \mathrm{~V} \text { or until any cell reaches } 3 \mathrm{~V}(2.5 \mathrm{~V} \text { for Battery G). } \\
\text { Battery G: At } 0{ }^{\circ} \mathrm{C} \text {, charge at a constant current of } \mathrm{C} / 2(12.5 \mathrm{~A}) \text { to } 32 \mathrm{~V} \text { or until any cell } \\
\text { reaches } 4.05 \mathrm{~V} \text {. Hold voltage constant and continue to charge until current tapers to C/50 } \\
(0.5 \mathrm{~A}) \text {. Discharge at approximately } 0.7 \mathrm{C}(17.14 \mathrm{~A}) \text { to } 24.0 \mathrm{~V} \text { or until any cell reaches } 2.5 \mathrm{~V} \text {. } \\
\text { Battery J: At } 23^{\circ} \mathrm{C} \text {, charge at a constant current of } \mathrm{C} / 5(5 \mathrm{~A}) \text { to } 32.4 \mathrm{~V} \text { or until any cell } \\
\text { reaches } 4.05 \mathrm{~V} \text {. Hold voltage constant and continue to charge until current tapers to C/50 } \\
(0.5 \mathrm{~A}) . \text { Discharge at } \mathrm{C} / 5(5 \mathrm{~A}) \text { to } 24.0 \mathrm{~V} \text { or until any cell reaches } 3 \mathrm{~V} \text {. }\end{array}$ \\
\hline & $\begin{array}{l}\mathrm{DC} \\
\text { impedance }\end{array}$ & $\begin{array}{l}\text { At LEO test temperature, charge at a constant current of C/5 (5 A) to } 32.4 \mathrm{~V} \text {. } \\
\text { Rest at OCV for } 2 \mathrm{hr} \text {. } \\
\text { Discharge at a constant current of } 1 \mathrm{C}(25 \mathrm{~A}) \text { for } 10 \mathrm{sec} \text {. } \\
\text { Rest at OCV for } 2 \mathrm{hr} \text {. } \\
\text { Discharge at a constant current of } 0.1 \mathrm{C}(2.5 \mathrm{~A}) \text { for } 2 \mathrm{hr} \text { (remove } 5 \mathrm{Ah}) \text {. } \\
\text { Repeat steps } 2 \text { to } 5 \text { four times (at each of } 80,60,40 \mathrm{and} 20 \text { percent } \mathrm{SOCs}) \text {. } \\
\text { Calculate the DC impedance. }\end{array}$ \\
\hline \multicolumn{2}{|l|}{ Cell balancing } & $\begin{array}{l}\text { Rest battery at open circuit at room temperature }\left(\sim 23^{\circ} \mathrm{C} \text { ) for at least } 2 \mathrm{hr} \text {. }\right. \\
\text { Individually drain discharge cells to } 2.75 \mathrm{~V} \text { (Battery } \mathrm{G}) \text { or } 2.5 \mathrm{~V} \text { (Battery } \mathrm{J} \text { ) using a } 1 \Omega \\
\text { resistor. } \\
\text { Allow voltages to recover at open circuit. } \\
\text { Charge at constant current, hold voltage constant and allow current to taper. } \\
\text { As needed, repeat steps } 1 \text { to } 3 \text {, to bring cell voltages closer together. } \\
\text { As needed, repeat steps } 1 \text { to } 3 \text { using a } 1.5 \Omega \text { resistor to bring cell voltages closer together. }\end{array}$ \\
\hline
\end{tabular}

In the second test, the batteries were soaked at $0{ }^{\circ} \mathrm{C}$ for at least $24 \mathrm{hr}$. They were then charged using a $\mathrm{CCCV}$ regime with a constant current of $0.5 \mathrm{C}$ to $32 \mathrm{~V}$ on the battery level or until any cell reached $4.05 \mathrm{~V}$. The voltage was then held constant while the current was allowed to taper until it reached C/50. The batteries were then discharged at $0.7 \mathrm{C}$ to $24 \mathrm{~V}$ on the battery level or until any cell reached $2.5 \mathrm{~V}$. The battery capacities were virtually identical at these conditions, delivering 25.6 and $25.7 \mathrm{Ah}$.

Baseline impedance tests were also performed on the batteries prior to initiating LEO cycling. Current-interrupt impedance tests were performed in which a series of pulses were discharged from the batteries at different states-of-charge (SOCs). The direct current (DC) impedance was then calculated as follows. The difference in voltage measured at the point $1 \mathrm{hr}$ after the pulse and at the lowest point during the pulse was calculated. This value was then divided by the difference in current measured at the point $1 \mathrm{hr}$ after the pulse (value equals zero) and the current during the pulse to determine the resistance or DC impedance.

The procedure for conducting these tests is described in table 2 under "500 and 1000 Cycle Characterization-DC Impedance". Identical tests were performed on each battery at 20 and $0{ }^{\circ} \mathrm{C}$. Figure 2 depicts the current and voltage profile versus time for the tests. The results for $20^{\circ} \mathrm{C}$ are shown in figure 3 . 


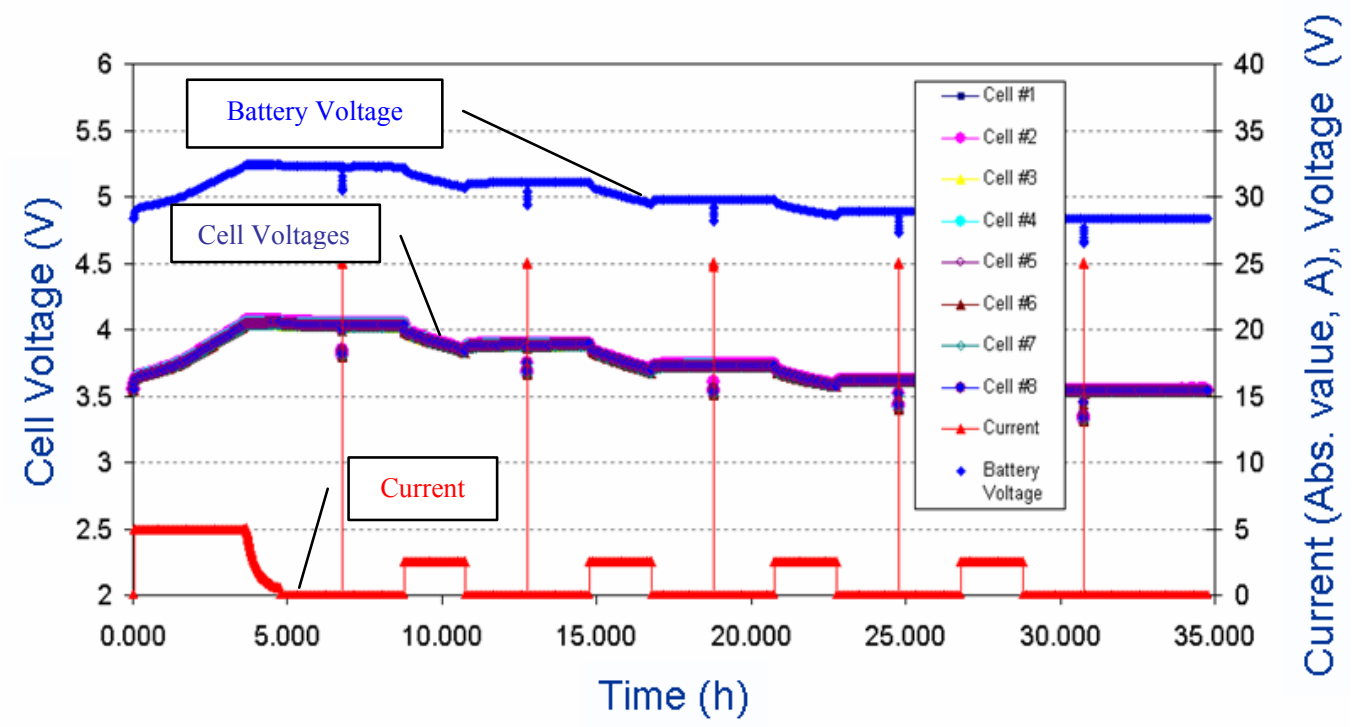

Figure 2.-DC impedance test - current and voltage profiles.

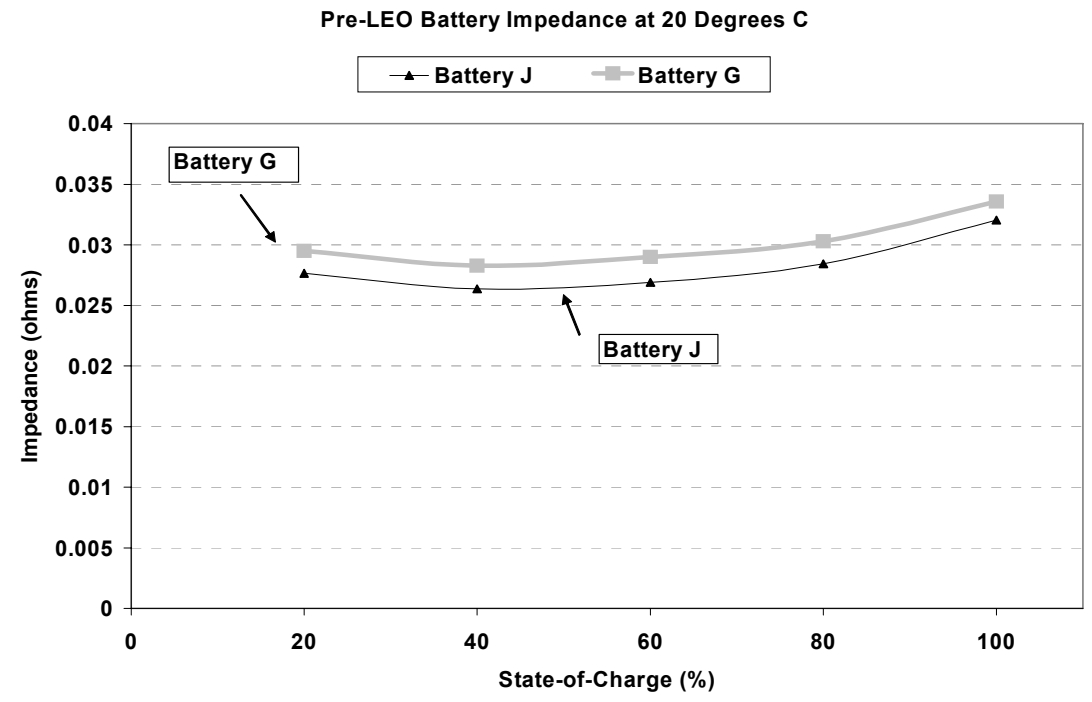

Figure 3.-Pre-LEO battery capacity at $20^{\circ} \mathrm{C}$.

\section{LEO Cycling}

A 90 min LEO orbit period was selected for this testing. While a spacecraft is on orbit, solar panels provide its primary power and provide energy to charge the batteries. The batteries are charged during a $55 \mathrm{~min}$ period of each orbit during which the spacecraft is exposed to sunlight. For this testing, the batteries are charged using a CCCV profile. Charge parameters for each battery are listed in table 2. Each battery is charged at $\mathrm{C} / 2(12.5 \mathrm{~A})$ to its battery or cell level cut-off voltage, whichever is reached first. Next, the battery voltage is held constant while the current is allowed to taper for the remainder of the $55 \mathrm{~min}$ charge period. This two-step charge regime allows for additional capacity to be added to the batteries once they have achieved their upper voltage cut-off limit, without increasing their voltage beyond the acceptable limits. 
For the remaining $35 \mathrm{~min}$ of the orbit, the sun is eclipsed by the Earth (with respect to the satellite), which results in the satellite being in shadow. During this time, the battery discharges to provide primary power to the spacecraft. A nominal discharge rate of $0.7 \mathrm{C}$ (about $17.14 \mathrm{~A}$ ) was required to discharge 40 percent of the capacity of the battery $(10 \mathrm{Ah})$ during the 35 min eclipse portion of the orbit. Specific discharge parameters for each battery are listed in table 2. A 40 percent depth-of-discharge (DOD) was chosen for this testing in order to test the outer envelope of possible DODs for Li-ion batteries for LEO applications.

Similarities in LEO test profiles among the two batteries include the same charge regimes, charge rates, discharge rates/DOD (nominally), and charge and discharge times.

Variations in the LEO cycling regimes of the two batteries occur within the test temperatures and the end-of-charge voltages (EOCVs). Battery $\mathrm{G}$ is being evaluated at $0{ }^{\circ} \mathrm{C}$ and Battery $\mathrm{J}$ is cycled at $23{ }^{\circ} \mathrm{C}$. The EOCV of Battery $\mathrm{J}$ is $30.4 \mathrm{~V}$, an average of $3.8 \mathrm{~V}$ per cell, while the EOCV of Battery $\mathrm{G}$ is $32.0 \mathrm{~V}$, an average of $4.0 \mathrm{~V}$ per cell.

Battery failure for this testing is defined as the point when the battery end-of-discharge-voltage (EODV) reaches $24 \mathrm{~V}$ or when any cell reaches $2.5 \mathrm{~V}$ during a LEO discharge. To date, each battery has accumulated over 12,000 cycles, equivalent to more than two years in LEO. The tests will continue until the batteries fail.

Figure 4 shows voltage versus capacity on the third LEO discharge for each battery. Each battery discharges approximately $10 \mathrm{Ah}$. Battery $\mathrm{G}$ has a higher mid-discharge voltage because it was charged to a higher voltage of $32 \mathrm{~V}$ and is therefore operating at a higher SOC, whereas Battery $\mathrm{J}$ was charged to only $30.4 \mathrm{~V}$. It is well documented in the literature that charging a battery to a lower EOCV can prolong its life, due to less electrolyte oxidation and subsequent SEI layer build-up at the electrode surface and increased cell resistance. However, there will be a decrease in the amount of available capacity when the battery is fully discharged because of its lower initial SOC. When a fixed amount of capacity is discharged on each cycle as occurs in this test profile, the result is a lower EODV caused by the lower voltage at the beginning of the discharge.

The EODVs of the batteries are shown in figure 5. At 12,000 cycles, the EODV of both batteries was well above the battery failure voltage of $24 \mathrm{~V}$. At this point, Battery $\mathrm{J}$ had an EODV of $27.02 \mathrm{~V}$ and Battery G had an EODV of $27.25 \mathrm{~V}$. The plot for Battery $\mathrm{J}$ also includes the EOCV, which is depicted as a solid line at $30.4 \mathrm{~V}$. The values at $32 \mathrm{~V}$ are the EOCVs for the periodic capacity checks. The temporarily lower EODVs for Battery J at around 2000 cycles are the result of errors in the chamber temperature. Stray values on the plot for Battery B are the result of test interruptions.

3rd LEO Discharge for Battery J and Battery G

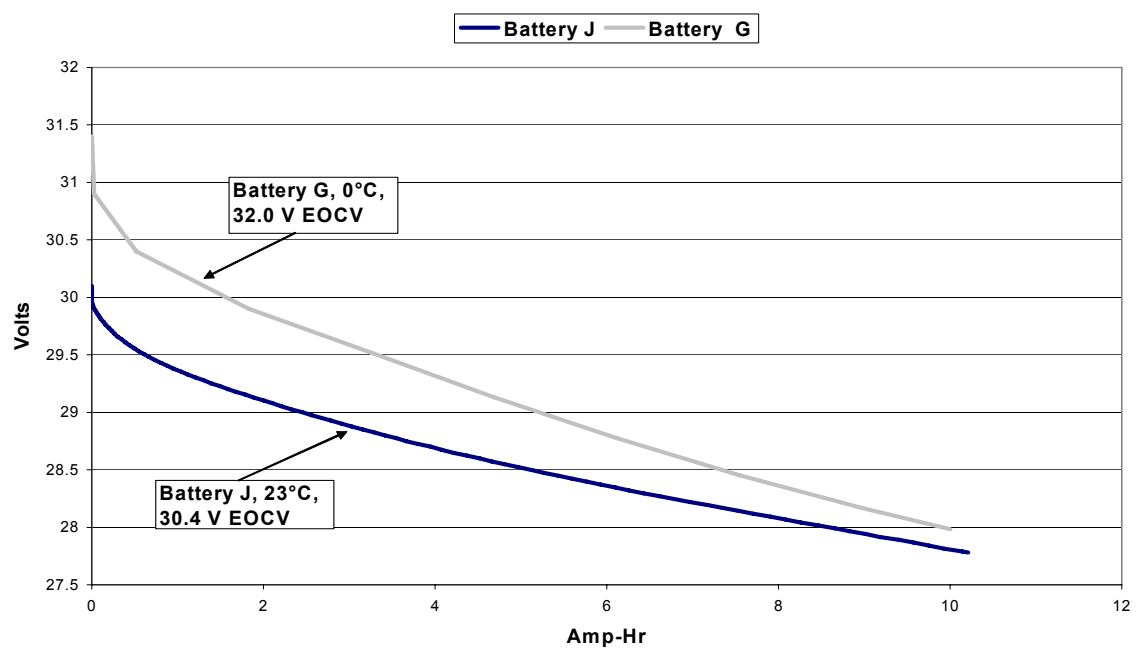

Figure 4.- Voltage versus capacity on the third LEO cycle. 


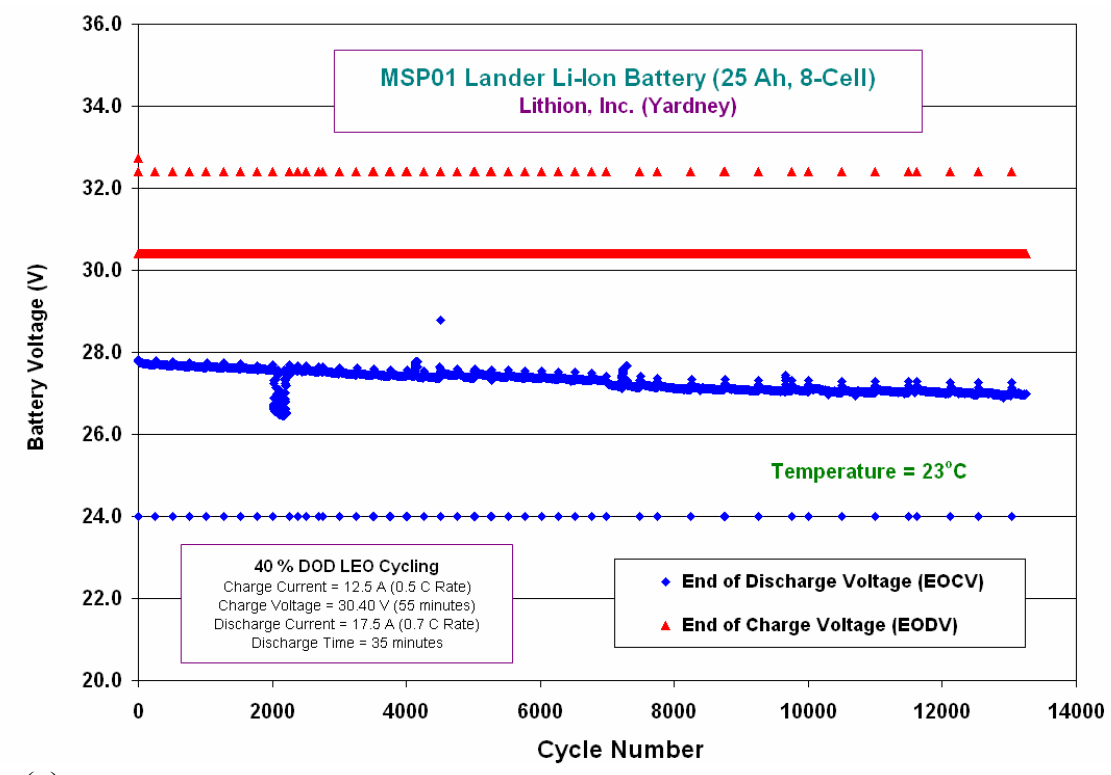

(a)

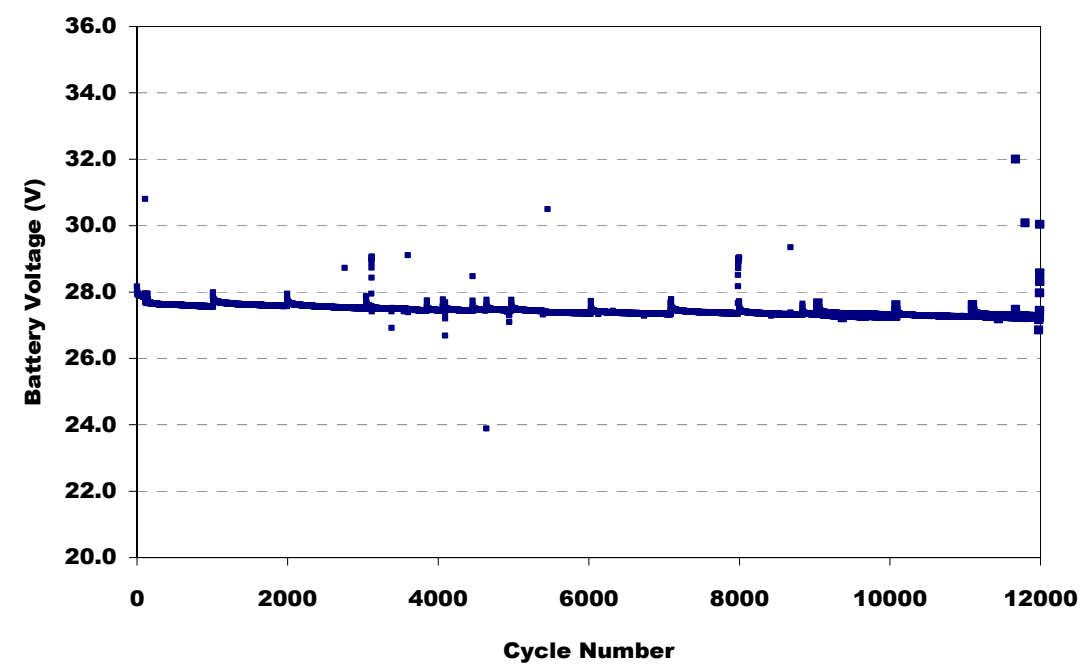

(b)

Figure 5.-End-of-discharge voltage versus cycles: (a) Battery $\mathrm{J}$ (also includes EOCV), and (b) Battery G.

The effects due to a lower EOCV in Battery $\mathrm{J}$ are somewhat offset by a lower rate of decline in its EODV. As seen in figure 4, Battery G's voltage curve is steeper than Battery J's so that by the end of the discharge period, the battery voltages are approaching each other. At cycle 3, Battery G has an EODV of $27.98 \mathrm{~V}$. At the same cycle number, Battery J measures $27.8 \mathrm{~V}$ after $10 \mathrm{Ah}$ have been discharged. Both batteries had EODVs of $27.36 \mathrm{~V}$ after approximately 6000 cycles. Thus, for cycles 3 through 6000 , the EODV of Battery J declined at a rate of approximately $73 \mu \mathrm{V} /$ cycle versus the higher rate of decline of $103 \mu \mathrm{V} /$ cycle for Battery $\mathrm{G}$ (rates were calculated for a period before the cells were balanced to eliminate EODV trend perturbations owing to cell balancing). 


\section{Periodic Characterization}

At specified intervals during testing, characterization is performed to observe battery aging effects. Periodic characterization consists of a capacity test and a current-interrupt DC impedance test that are performed every 500 or 1000 cycles. A consistent set of criteria was established to determine when cell balancing would occur on each battery. Cell balancing is performed during a regularly scheduled characterization interval if the cell voltage dispersion exceeds 100 millivolts $(\mathrm{mV})$ on charge or $80 \mathrm{mV}$ on discharge.

\section{Capacity}

Full capacity (100 percent DOD) and percentage capacity lost over initial pre-LEO capacity for each battery for every 1000 cycle characterization are shown in figure 6 . The first capacity measurement corresponds to the full capacity value measured during pre-LEO characterization at the conditions listed under "500 and 1000 Cycle Characterization-100 percent DOD Capacity Test" for each battery. This value was 31.4 Ah for Battery J and 25.7 Ah for Battery G.

As expected, Battery $G$ exhibits lower capacity under these conditions for several reasons. It is charged at a lower temperature, at a higher rate, and to a lower EOCV than Battery $\mathrm{J}$ (these charge rate and charge voltage correspond to the periodic capacity measurements only). All of these factors lead to less available capacity in the battery. Additionally, Battery $\mathrm{G}$ is discharged at a lower temperature and at a higher rate than Battery J, conditions which tend to yield less delivered capacity (this discharge rate corresponds to the periodic capacity measurements only).

The batteries show similar percentage capacity loss as compared to their pre-LEO capacity in the cycles before the cells were balanced. After cell balancing, both batteries exhibit a lower rate of capacity fade as compared to before cell balancing. Battery $J$ shows a slightly higher percentage of capacity loss after cell balancing than Battery G. Cell balancing is discussed on further detail later in the paper.

Lower capacity fade during lower temperature cycling is consistent with results observed from tests performed on prototype $20 \mathrm{Ah}$ cells cycled at -20 and $25^{\circ} \mathrm{C}$ (ref. 4). The prototype cells are of the same chemistry as the cells in the batteries discussed herein and were also manufactured by Yardney Technical Products. This effect is attributed to an increased rate of impedance rise with increasing temperature. A higher rate of DC impedance rise is evident in Battery $\mathrm{J}$, which is cycling at $23{ }^{\circ} \mathrm{C}$, versus Battery B, which is cycling at $0^{\circ} \mathrm{C}$. DC impedance of the batteries is discussed in detail in the following text.

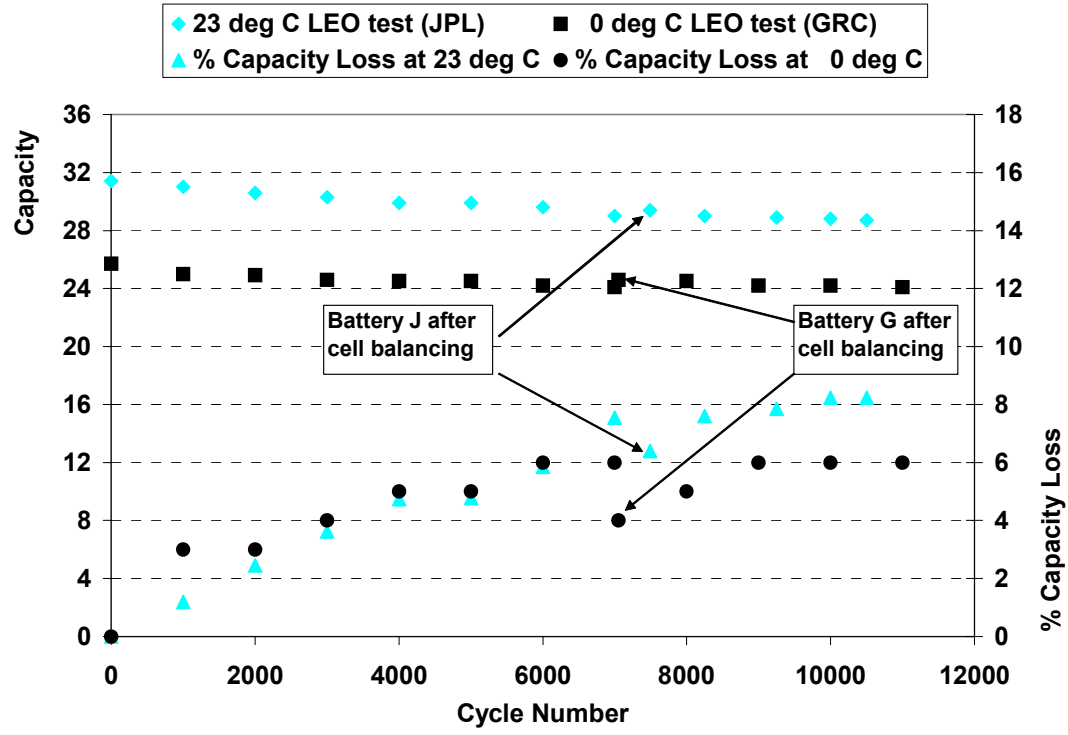

Figure 6.-Capacity and percentage capacity loss versus cycle. 


\section{Impedance}

Figure 7 shows the DC impedance of the batteries at different cycles. Battery $\mathrm{G}$ had higher initial impedance than Battery $\mathrm{J}$ and continues to show higher impedance throughout cycling. However, the impedance of Battery $J$ increased at a higher average rate during the first 10000 cycles than Battery $G$, resulting in much higher percentage changes in impedance over the pre-LEO impedance at cycles 5000 and 10000 , as seen in figure 8 . At 100 percent SOC, Battery J's impedance increased at an average rate of $3 \mu \Omega$ per cycle, while Battery G's impedance increased at rate of $2.7 \mu \Omega$ per cycle on average. These results were calculated using the pre-LEO impedance measurements taken at $20{ }^{\circ} \mathrm{C}$ for battery $\mathrm{J}$ and the $0{ }^{\circ} \mathrm{C}$ for Battery $\mathrm{G}$.

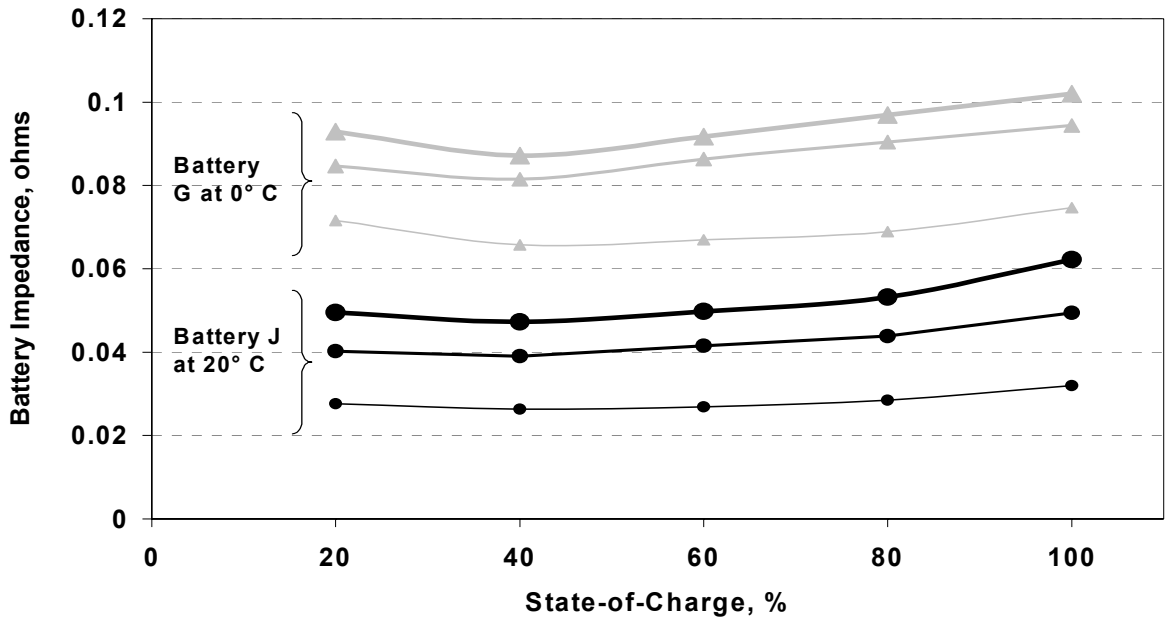

- Pre-LEO at 0 deg C -5000 Cycles at 0 deg C -10000 Cycles at 0 deg C

Figure 7.--Impedance of Battery $\mathrm{G}$ and Battery $\mathrm{J}$ at different cycle numbers.

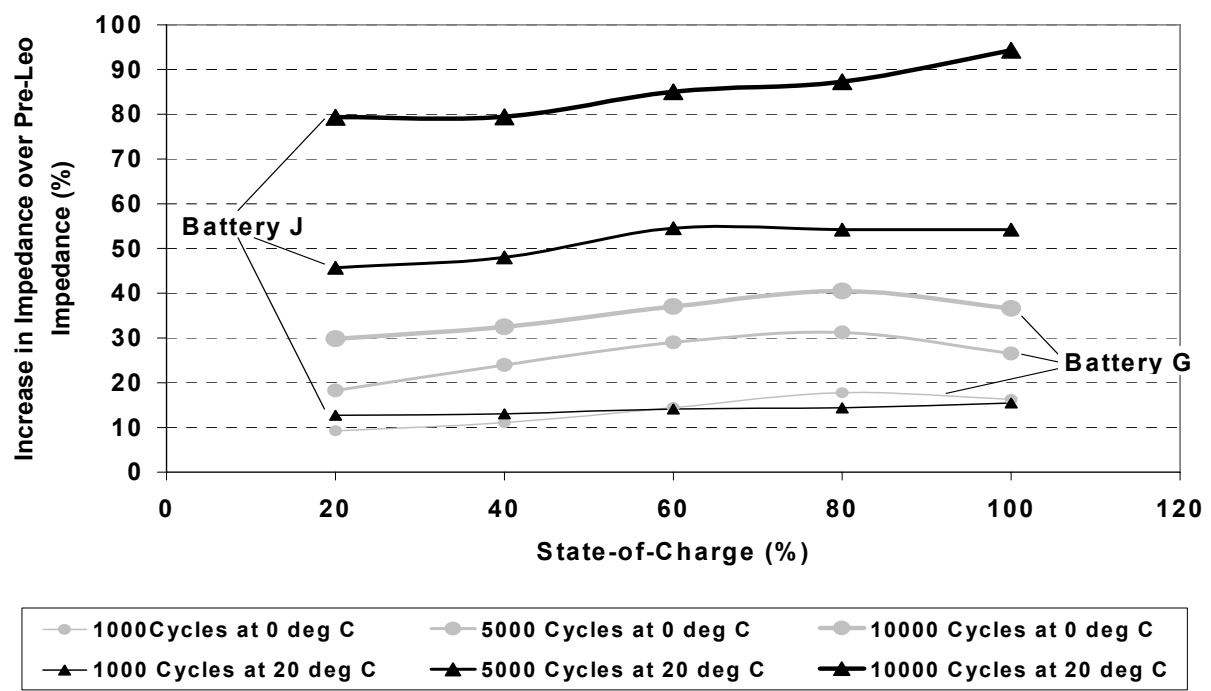

Figure 8.-Percent change in battery impedance with cycling. 
From 0 to 5000 cycles, the impedance of Battery $\mathrm{J}$ increased at 3.5 microohms per cycle on average. Its impedance growth rate temporarily accelerated between 5000 to 7000 cycles to an average of $4.4 \mu \Omega$ increase per cycle. The battery then showed a much lower than average impedance growth rate of $1.4 \mu \Omega$ per cycle from cycles 7000 to 10000 .

Battery G's impedance growth rate was much higher in the early cycles than in later cycles, showing an average impedance of $3.8 \mu \Omega$ per cycle for the first 6000 cycles. This growth rate then slowed to $2.4 \mu \Omega$ per cycle from cycles 7000 to 10000 .

\section{Cell Balancing}

Cell balancing was performed at the 7000 cycle characterization interval for Battery G and at 7500 cycles for Battery J. Table 3 lists the end-of-discharge (EOD) cell voltage dispersions during the LEO cycles immediately before and just after cell balancing for each battery.

Figure 9 shows the effect of cell balancing on the EOD cell voltage dispersion. For Battery $J$, the EOD cell voltage dispersion during LEO cycling was reduced to just $11 \mathrm{mV}$ as a result of cell balancing. For Battery G, the EOD cell voltage dispersion was reduced to $32 \mathrm{mV}$ in the LEO cycles immediately following cell balancing. In subsequent LEO cycles, the EOD cell voltage dispersion continued to decrease. By 8000 cycles, the dispersion had been further reduced to $26 \mathrm{mV}$, where it remained relatively constant over the next 4000 cycles.

Current performance trends indicate that this battery design can support 30,000 cycles to 40 percent DOD in LEO at both 23 and at $0{ }^{\circ} \mathrm{C}$, however, cell balancing would be necessary. This could be accomplished either through continuous charge management on each cycle through the use of charge balancing electronics, or if the mission requirements allow, through an occasional drain discharge of individual cells (electrically isolated).

TABLE 3.-EOD CELL VOLTAGE DISPERSION BEFORE AND AFTER CELL BALANCING

\begin{tabular}{|l|c|c|}
\hline & Battery J & Battery $\mathrm{G}$ \\
\hline EODV dispersion before cell balancing, $\mathrm{mV}$ & 55 & 39 \\
\hline EODV dispersion after cell balancing, $\mathrm{mV}$ & 11 & 32 \\
\hline
\end{tabular}

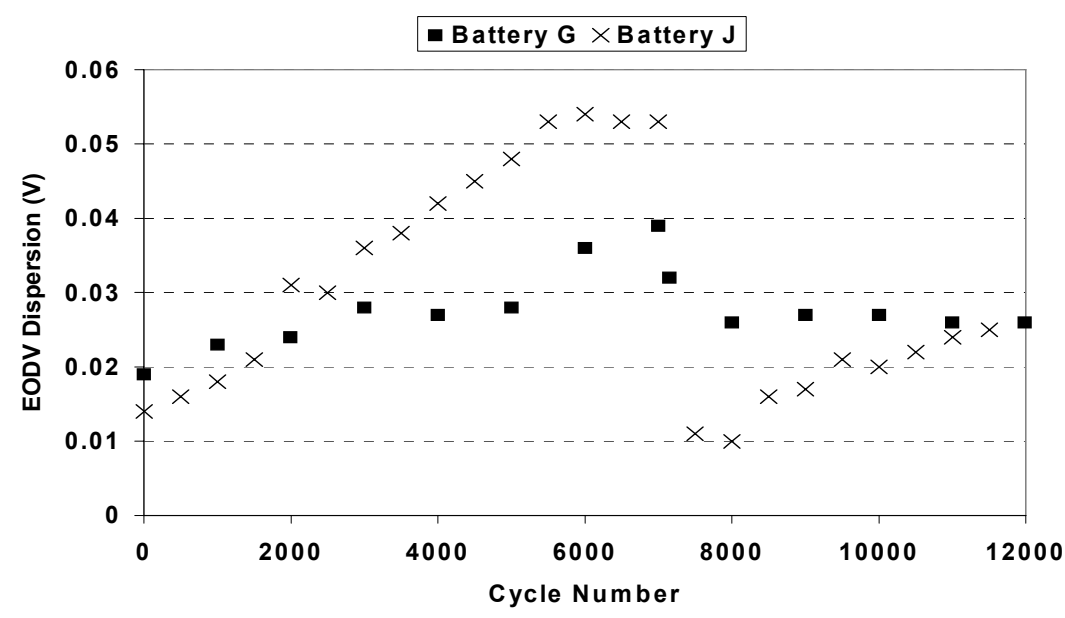

Figure 9.-End-of-discharge cell voltage dispersion versus cycle. 


\section{Summary}

Two flight batteries built with cells from the same lot are undergoing LEO life cycle testing at different laboratories. Test conditions were coordinated to perform similar tests at different temperatures and EOCVs. At their respective LEO test conditions, Battery J exhibited higher capacity and lower DC impedance than Battery $\mathrm{G}$ during pre-LEO characterization tests. Battery $\mathrm{G}$ was cycled at the colder temperature and higher end-of-charge voltage. It exhibited lower initial capacity at its LEO cycling conditions and higher initial impedance, but has shown less impedance growth while cycling.

The batteries show similar percentage capacity loss as compared to their pre-LEO capacity in the cycles before the cells were balanced. After cell balancing, both batteries exhibit a lower rate of capacity fade as compared to before cell balancing. Battery $\mathrm{J}$ shows a slightly higher percentage of capacity loss after cell balancing than Battery G.

Both batteries have achieved over 12,000 cycles, the equivalent of over two years in LEO orbit. At 12,000 cycles, the EODV of both batteries was well above the battery failure voltage of $24 \mathrm{~V}$. Current performance trends indicate that this battery design is capable of delivering 30,000 cycles to 40 percent DOD in LEO, provided that some method of cell balancing is employed.

\section{References}

1. Salomon, M., Lin, H., Plichta, E.J., and Hendrickson, M.,"Temperature Effects on Li-Ion Cell Performance," Advances in Lithium-Ion Batteries, edited by W.A. van Schalkwijk, and B. Scrosati, Kluwer Academic/Plenum Publishers, New York, 2002, pp. 309-344.

2. Reid, C., "Low Temperature Low-Earth-Orbit Testing of Mars Surveyor Program Lander Lithium-Ion Battery," Lithium-Ion Battery for Spacecraft, IECEC, August, 2005.

3. Reid, C., "Low Temperature Life-Cycle Testing of a Lithium-Ion Battery for Low-Earth-Orbiting Spacecraft," 2004 NASA Aerospace Battery Workshop, November 16-18, 2004.

4. Smart, M.C., Ratnakumar, B.V., Whitcanack, L., Surampudi, S., Lowry, L., Gitzendanner, R., et al., "Performance Characteristics of Yardney Lithium-Ion Cells for the Mars 2001 Lander Application," AIAA-2000-2914, 2000.

5. Smart, M.C., Ratnakumar, B.V., Whitcanack, L., Surampudi, S., Byers, J., and Marsh, R., "Performance Characteristics of Lithium-Ion Cells for NASA's Mars 2001 Lander Application," IEEE AES Systems Magazine, November, 1999, pp. 36-42.

6. Smart, M.C., Ratnakumar, B.V., Whitcanack, L.D., Chin, K.B., Surampudi, S., Gitzendanner, R., et al., "Lithium-Ion Batteries for Aerospace," IEEE AESS Systems Magazine, January 2004, pp. 18-25. 


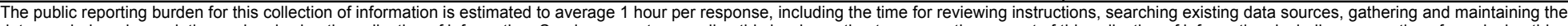

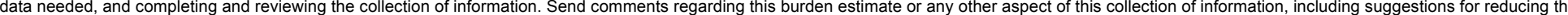

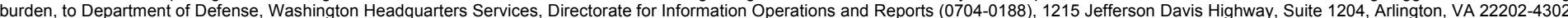

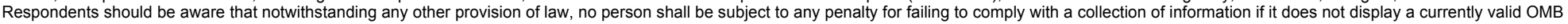
control number.

PLEASE DO NOT RETURN YOUR FORM TO THE ABOVE ADDRESS

\begin{tabular}{|l|l|l|l}
\hline 1. REPORT DATE (DD-MM-YYYY) & 2. REPORT TYPE & 3. DATES COVERED (FrOm - To)
\end{tabular}

01-12-2007

\section{TITLE AND SUBTITLE}

Technical Memorandum

Performance and Comparison of Lithium-Ion Batteries Under Low-Earth-Orbit Mission

Profiles

5c. PROGRAM ELEMENT NUMBER

\section{AUTHOR(S)}

Reid, Concha, M.; Smart, Marshall, C.; Bugga, Ratnakumar, V.; Manzo, Michelle, A.; Miller,

Thomas, B.; Gitzendanner, Rob

7. PERFORMING ORGANIZATION NAME(S) AND ADDRESS(ES)

National Aeronautics and Space Administration

John H. Glenn Research Center at Lewis Field

Cleveland, Ohio 44135-3191

\section{SPONSORING/MONITORING AGENCY NAME(S) AND ADDRESS(ES)}

National Aeronautics and Space Administration

Washington, DC 20546-0001

\section{DISTRIBUTION/AVAILABILITY STATEMENT}

Unclassified-Unlimited

Subject Categories: 15, 18, 20, 44, and 91

Available electronically at http://gltrs.grc.nasa.gov

This publication is available from the NASA Center for AeroSpace Information, 301-621-0390

\section{SUPPLEMENTARY NOTES}

\section{ABSTRACT}

The performance of two $28 \mathrm{~V}, 25$ Ah lithium-ion batteries is being evaluated under low-Earth-orbit mission profiles for satellite and orbiter applications. The batteries are undergoing life testing and have achieved over 12,000 cycles to 40 percent depth-of-discharge.

\section{SUBJECT TERMS}

Lithium batteries; Storage batteries; Electric batteries; Electrochemical cells; Energy storage; Space missions; Mars missions; Spacecraft power supplies; Electric power supplies; Low Earth orbits

\begin{tabular}{|l|l|l|l|l|}
\hline \multicolumn{2}{|l|}{ 16. SECURITY CLASSIFICATION OF: } & $\begin{array}{l}\text { 17. LIMITATION OF } \\
\text { ABSTRACT }\end{array}$ & $\begin{array}{c}\text { 18. NUMBER } \\
\text { OF } \\
\text { PAGES }\end{array}$ \\
\begin{tabular}{|l|l|l|} 
a. REPORT \\
U
\end{tabular} & $\begin{array}{l}\text { b. ABSTRACT } \\
\text { U }\end{array}$ & $\begin{array}{l}\text { c. THIS } \\
\text { PAGE } \\
\text { U }\end{array}$ & UU & 18 \\
\end{tabular}

\section{5f. WORK UNIT NUMBER}

WBS 083229.04.15.01.01

\section{PERFORMING ORGANIZATION \\ REPORT NUMBER}

E-16018

DPONSORING/MONITORS

NASA

11. SPONSORING/MONITORING

REPORT NUMBER

NASA/TM-2007-214826 

